\title{
TAFSIR IMAM AL-BAIDHAWI DALAM PERSFEKTIF HERMENEUTIK
}

\author{
R. Edi Komarudin \\ Fakultas Adab dan Humaniora \\ UIN Sunan Gunung Djati Bandung
}

\begin{abstract}
Abstrak
Tafsir Imam Baidhawi ini menjadi salah satu kajian pokok ilmu tafsir di lingkungan pesantren salafiyah dan masih menjadi objek kajian para pemerhati al-Quran. Tujuan dari penelitian ini adalah untuk mengetahui pendekatan, metode, corak dan sumber penafsiran al-Qur'an Imam Baidhawi. Metode yang digunakan dalam penelitian ini adalah metode deskriptif analisis. Dengan metode ini, peneliti mendeskripsikan dan menganalisis makna ayat-ayat al-Qur'an menurut penafsiran Imam alBaidhawi, dengan kata lain menggunakan metode analisis isi teks (content analysis). Penelitian ini juga menggunakan metode tafsiry (eksplanatory) yakni metode menafsirkan bahasa yang digunakan Imam Baidhawi sebagai mufassir. Melalui metode ini, gagasan pemikiran atau pesan dari mufassir dapat dipahami dan diambil manfaatnya. Penelitian tentang penafsiran Imam Baidhawi dalam Tafsir Anwar al-Tanzil wa Asrar al-Takwil ini menghasilkan beberapa temuan berikut : 1) Dalam kitab Tafsîr Anwâr al-Tanẑ̂l wa Asrâr al-Takwîl, Imam al-Baidhawi tidak hanya melakukan penafsiran, tetapi juga pentakwilan terhadap ayat-ayat al-Quran dengan pendekatan kaidah bahasa Arab. 2) Imam alBaidhawi menyajikan ayat-ayat hukum yang berkenaan dengan masalah fikih secara ringkas dengan menunjukkan kecenderungannya terhadap Mazhab Syafi'i yang dianutnya. 3). Ada dua kitab tafsir penting yang dirujuk Imam al-Baidhawi dalam menyusun kitab tafsir ini. Pertama, kitab Tafsir al-Kasysyâf karya al-Zamakhsyari, namun beliau meninggalkan pendapat al-Zamakhsyari yang berhubungan dengan paham Muktazilah. Kedua, kitab Al-Tafsîr al-Kabîr karya Fakhruddin alRazi yang menyebabkan Imam Baidhawi tenggelam dalam pembahasan tentang ayat-ayat yang berhubungan dengan fenomena alam sehingga mengantarkan karya tafsirnya kedalam corak tafsir ilmi.
\end{abstract}

Key Word: Tafsir, Imam Baidhawi, metode penafsiran, bahasa, riwayat, internal relationship, interpretasi ilmiah.

\section{PENDAHULUAN}

Dalam studi-studi tafsir alQuran al-Karim, nama al-Baidhawi sudah tidak asing lagi, terutama melalui karya tafsir monumentalnya yakni Tafsîr Anwâr al-Tanzîl wa Asrâr al-Takwîl (Cahaya al-Quran dan Rahasia Takwil). Karya-karya yang berupa komentar (hasyiyah) pun sudah banyak di tulis yang ditujukan untuk mengomentari berbagai hal yang ada pada kitab tafsir karyanya itu.

Dari sekian komentar yang ada, ada yang memandang bahwa tafsir al-Baidhawi ini adalah bukan karya orsinil Imam al-Baidhawi, melainkan hasil saduran dari karya- 
karya yang pernah ada sebelumnya. Namun ada juga yang mempunyai pandangan bahwa tafsir Imam alBaidhawi adalah merupakan karya orsinil Imam al-Baidhawi. Di satu pihak artikel ini hendak menyampaikan hasil penelusuran permasalahan orsinalitas karya tafsir tersebut, dan di pihak lain merupakan gambaran atas hasil analisis Tafsir Imam al-Baidhawi tersebut dengan persfektif Hermeneutika. Hal ini dipandang sebagi sesuatu yang penting sebagai upaya menjembatani pemahaman konsep Tafsir dan Hermeneutik yang telah menjadi suatu nomenklatur bidang ilmu.

$\begin{array}{ccc} & \text { Tafsir sebagai sebuah disiplin } \\ \text { ilmu } & \text { telah memulai }\end{array}$
perkembanangannya di dunia Timur Tengah dengan Peradaban Islam yang mewadahinya. Sementara Hermeneutik mengawali perkembangannya di dunia Eropa khususnya Yunani. Ada satu titik singgung yang awal mula perkembangan kedua ilmu ini dipandang sama, yaitu bahwa keduanya pada awalnya merupakan ilmu yang digunakan untuk menafsirkan teks kitab suci. Namun juga sekaligus ada perbedaan yang siginifikan, yaitu bahwa teks kitab suci yang ditafsirkan dengan Tafsir adalah teks al-Quran. Sementara teks kitab suci yang ditafsirkan oleh Hermeneutik adalah teks Bibel. Namun, cara kerja kedua disipilin ilmu ini mempunyai kemiripan walaupun belum bisa disebut mempunyai kesamaan. Dalam cara kerjanya secara umum, Tafsir mengawalinya dengan upaya menjelaskan aspek bahasa, kemudian melanjutkannya dengan uraian penafsirannya. Begitupun Hermeneutik, langkah awal dalam cara kerja Hermeutik adalah menjelaskan aspek kebahasaan dengan lingkup makna-makna semantis, yang dalam istilah Hermeneutik disebut sebagai langkah explanasi. Setelah langkah ini berlanjut peda langkah menafsirkan dengan mempertimbangkan banyak hal. Dalam langkah ini, Hermeneutik menyebutnya dengan langkah interpretasi.

\section{PEMBAHASAN}

Nama lengkap Imam alBaidhawi adalah al-Imam Abdullah bin Umar bin Muhammad bin Ali alSyiraji Abu Said Abu al-Khair Nashiruddin al-Baidhawi, seorang mufassir, ahli hadits, teolog Asy'ariyah, ahlli fiqih dan ushul fiqh yang bermadzhab Syafi'i. Panggilan Baidhawi dinisbatkan kepada sebuah daerah tempat kelahirannya yang bernama al-Baidha', sebuah distrik di daerah Syiraz, Persi. Beliau seorang putra hakim agung di Fars (Iran Barat daya), tempat awal ilmunya tumbuh dan berkembang. (Rohman Ritonga, dkk.,1997; 81)

Imam al-Baidhawi adalah ulama besar pada masa abad ketujuh Hijriah yang tekun ibadah dan shaleh. Beliau pernah menjabat sebagai qadhi di daerah Syiraz namun kemudian dipecat karena kritik tajam yang ia lakukan terhadap penguasa waktu itu. Kemudian Imam al-Baidhawi pindah ke Tibriz dan mengembangkan ilmu pengetahuannya disana. Kebesaran dan kedalaman serta keahliannya dalam berbagai disiplin ilmu memikat banyak murid untuk datang berguru kepadanya dalam bidang ushul fiqih dan tafsir. Beliau juga masyhur dengan keahliannya berdebat dan dalam ilmu berdiskusi. 
(Muhammad Husen Adz-Dzahabi, 1976; 297)

Setelah lama mengabdi kepada pemerintah sebagai hakim di Syiraj, kemudian Imam al-Baidhawi pindah ke Tibriz. Beliau menetap disana sampai akhir hayatnya. Para ulama berbeda pendapat dalam menetapkan tahun wafat Imam alBaidhawi. Ibnu Katsir dan Jalaluddin al-Suyuthi menyatakan bahwa tahun wafat Imam al-Baidhawi adalah 685 H/ 1286 M. Menurut Imam Tajuddin al-Subki dan Al-Asnawi tahun 691 H/1291 M, (Muhammad Husen AdzDzahabi, 1976; 297). Sedangkan menurut Syaikh Al-Maraghi tahun 692 H / 1292 M. (Mushtafa Ahmad al-Maraghi, 1974; 74), Imam alBaidhawi adalah ulama ternama sekaligus sebagai penulis produktif. Beliau telah menghasilkan karyakaryanya dalam berbagai disiplin ilmu, seperti teologi, tata bahasa, usul fiqh, fiqh, logika dan metafisika. Diantara karya-karya Imam alBaidhawi adalah: (Mushtafa Ahmad al-Maraghi, 1974; 74)

1. Mukhatashar al-Kasysyaf (Anwar al-Tanzil wa-Asrar al-Takwil)

2. Al-Minhaj fi al- Ushul

3. Syarh al-Minhaj al-ushul

4. Mukhtashar Ibnu al-Hajib fi al-Ushul.

5. Syarh Muntakhab fi alUshul.karya al-Imam Fakhruddin

6. Syarh al-Mathali (Mantiq)

7. Al-Idhah (Ushuluddin)

8. Al-Ghayah Al-Qushwa (Fiqh)

9. Al-Thawali (Kalam)

10. Syarh al-Kafiyah li ibn alhajib

11. Syarh al-Mashabih dan lainlain.

\section{Karakteristik Tafsir Al-Baidhawi}

Satu dari sekian banyak tulisan Imam al-Baidhawi yang paling monumental adalah karya tafsirnya yang berjudul Anwâr al-Tanzîl wa Asrâr al-Takwîl (Cahaya Pewahyuan dan Rahasia Penafsiran). Tafsir AlBaidhawi dapat dikatakan sebagai tafsir yang paling dikenal di dunia Barat dan paling luas dibaca oleh kalangan umat Islam di dunia. Sebagaimana dituturkan oleh Richard Bell, bahwa para cendikiawan Eropa sering menganggap kitab tafsir tersebut sebagai penjelasan standard tentang Al-Quran. (W. Montgomery Watt, Bell's Introduction to the Qur'an, Terj. Lilian D. Tedjasudhana, 998);149)

Dalam beberapa hal, keutamaan dan popularitas tafsir AlBaidhawi hanya dapat disaingi oleh Tafsir al-Jalalain karya Jalaluddin alMahalli (w. 864/1459) dan Jalaluddin al-Suyuthi (w. 911/1505). Salah satu keutamaan dan popularitas tafsir al-Baidhawi dapat dilihat mislanya dari kenyataan bahwa beberapa bagian tafsirnya telah diterjemahkan ke dalam bahasa Inggris dan Perancis. Disamping itu para ulama terdahulu telah banyak menulis komentar (hasyiyah) terhadap kitab tafsir tersebut. Tidak hanya sebanyak delapan puluh hasyiyah seperti diperkirakan Edwin F Calverley, tetapi juga sebagaimana hasil riset Majma al-Malaki di Amman, lebih dari tiga ratus hasyiyah mendasarkan komentarnya kepada tafsir Al-Baidhawi. Hasyiyah-hasyiyah Tafsir AlBaidhawi diantaranya ditulis oleh Abu al-Fadhal al-Qurasyi al-Shadiqi al-Khatib yang popular dengan alKazaruni, Imam Shihab, Syaikh Zadah dan Imam Nawawi. 
Kehadiran Tafsir al-Baidhawi ini dimaksudkan sebagai buku pedoman untuk pengajaran di sekolah tinggi atau sekolah masjid. Oleh karenanya Al-Baidhawi memberikan secara ringkas semua yang paling baik dan paling masuk akal dari penjelesan-penjelasannya dibanding kitab-kitab tafsir sebelumnya, termasuk tafsirantafsiran lainnya yang penting. (Jurnal Ulumul Quran No. 3 VII/1996.)

Imam al-Baidhawi menulis tafsirnya dengan menyebut keseluruhan ayat al-Quran secara tahlili dengan menyajikan tafsir surah demi surah dalam bentuk penggalan-penggalan ayat demi ayat atau kalimat demi kalimat sesuai dengan urutan atau tartib mushaf yang dimulai dengan surah alFatihah dan diakhiri dengan surah alNas. Sebelum menafsirkan ayat-ayat dalam suatu surah, Imam alBaidhawi menuturkan kronologis turunnya surah Makiah atau Madaniyah disertai penjelasan jumlah ayat. Dan pada bagian akhir setiap jilid selalu dilampirkan indeks tema-tema penting yang ditafsirkan Imam al-Baidhawi.

$$
\text { Para ulama seperti }
$$

Muhammad Husein Al-Dzahabi, Ali al-Shabuni, Manna Khalil alQaththan dan Hasbi al-Shiddiqi mengkategorikan Tafsir al-Baidhawi ke dalam kelompok tafsir bi al-rayi. Namun menurut hemat penulis, pendekatan Imam al-Baidhawi dalam Tafsir Anwar al-Tanzil wa Asrar alTakwil tidak sepenuhnya ra'yi seperti halnya bersandar kepada kaidah-kaidah Bahasa Arab dalam penafsirannya, tetapi ada kalanya juga dengan menggunakan pendekatan bi al-Matsur. Hal ini dapat ditunjukkan ketika Beliau menyandarkan penafsiran suatu ayat dengan riwayat atau ayat-ayat alQuran yang lainnya.

\section{Sistematika Penulisan}

Kitab Tafsir Al-Baidhawi terdiri dari lima juz yang disajikan dalam dua jilid terbitan Al-Haramain Singapura. Jilid pertama terdiri dari dua juz yang berisi enam surah. Juz pertama memuat dua surah, sedangkan juz kedua berisi empat surah. Jilid kedua terdiri dari tiga juz yang berisi 108 surah. Juz ketiga berisi 12 surah. Juz keempat berisi 18 surah. Adapun juz kelima berisi 78 surah.

Dalam jilid pertama Tafsîr Anwâr al-Tanzîl wa Asrâr al-Takwîl diawali dengan pengantar singkat yang berisi pandangan Imam Baidhawi terhadap al-Quran serta latar belakang penulisan tafsirnya. Kemudian Ia menafsirkan surah demi surah dengan pemenggalan ayat demi ayat setelah sebelumnya menuturkan kronologis turunnya ayat (Makiyah atau Madaniyah) serta jumlah ayat dalam satu surah. Namun sangat disayangkan, penyajian ayat-ayat yang ditafsirkannya tidak ditandai dengan nomor ayat sehingga tidak cukup mudah bila kita hendak mencari ayat-ayat tertentu yang Beliau tafsirkan. Pada bagian akhir setiap juz dilampirkan daptar isi dari juz tersebut berdasarkan tema-tema pokok yang Beliau pilih untuk ditafsirkan.

\section{Hermeneutika Al-Baidhawi}

Hermeneutika

(Hermeneutics) berasal dari kata kerja dalam Bahasa Yunani "hermeuneuin" yang berarti "menjelaskan" "menterjemahkan" dan "mengekspresikan". Sumber lain menyebutkan bahwa "hermeneutic" 
merujuk pada Hermes, nama seorang utusan tuhan dalam mitologi Yunani yang bertugas menjelaskan perintah-perintah tuhan kepada manusia, dengan kata lain menjembatani antara dunia langit (divine) dengan dunia manusia. Berangkat dari mitologi ini, para ahli menjelaskan bahwa problem hermeneutika pada dasarnya adalah bagaimana menjelaskan dan menterjemahkan peristiwa atau teks yang telah lalu ke dalam eksistensi manusia saat ini. Pengertian ini tersirat dalam al-Quran surah al-Nahl 44, Allah SWT berfirman أنزلنا إليك . Walaupun secara etimologis tidak ada perbedaaan antara hermeneutika dengan penafsiran, tetapi dalam prakteknya kedua kata tersebut dapat dibedakan. Penafsiran biasanya disejajarkan dengan praktik penafsiran, sedang hermeneutika adalah teori atau metode interpretasi. Dalam pengertian metode interpretasi inilah penulis menggunakan istilah hermeneutika. (Jurnal Ulumul Quran No. 3 VII/1996, h. 38)

Dalam melakukan interpretasi terhadap teks-teks kitab suci, para ahli hermeneutika tidak menolak bahwa pelaku interpretasi dalam hal ini mufassir- tidak berada dalam keadaan kosong. Dia akan membawa pra-anggapannya ke dalam teks tersebut. Fenomena ini biasa disebut dalam hermeneutika sebagai salah satu dimensi dari "lingkungan hermeneutika" (the hermeneutical circle). Dimensi lainya (kedua) dari lingkungan Hermeneutika adalah suatu konsep yang menyatakan bahwa untuk memahami secara keseluruhan, kita harus memahami partikularnya, bagian-bagiannya dan begitu juga
Tafsir Imam Al-Baidhawi Dalam Persfektif Hermeneutik

sebaliknya. (Warner G. Jeanrond, 1991: 5-6). Redaksi yang sama juga dikemukakan oleh Antony, C. Thiselton) dalam bukunya New Horizon in Hermenutik. (Antony. C. Thiselton, 1992 : 221-228) Praanggapan seorang penafsir al-Quran dapat berupa pengetahuannya tentang bahasa Arab, puisi, asbab alnuzul (konteks dan intra teks) dan munasabah (inter teks). Aspek inilah yang turut mewarnai teknik dan disiplin penulisan seorang mufassir ketika menafsirkan al-Quran.

Kesadaran Al-Baidhawi terhadap Hermeneutika dan metode penafsiran dapat kita baca dalam pengantar Anwâr al-Tanzîl wa Asrâr al-Takwîl yang ia tulis. Ada dua alasan yang melatarbelakangi Imam Baidhawi menulis Tafsir Anwar alTanzil wa Asras al-Takwil. Pertama, Imam al-Baidhawi memandang bahwa ilmu yang paling tinggi derajatnya dan paling mulia adalah ilmu tafsir. Ilmu tafsir merupakan pemimpin ilmu-ilmu agama dan kepalanya, fondasi agama dan basisnya. Tak pantas seorangpun berbicara tentang tafsir kecuali mereka menguasai pengetahuan agama, baik yang usul maupun yang furu' serta ahli dalam disiplin bahasa Arab dan sastra. Dalam hal ini Imam al-Baidhawi memandang tafsir sebagai ilmu agama yang tertinggi derajatnya dalam ilmu-ilmu agama, sebagaimana dituturkannya dalam pengantar Anwar al-Tanzil wa Asrar al-Takwil sebagai berikut: (Umar bin Muhammad al-Syiraji al-Baidhawi, :

5-6)

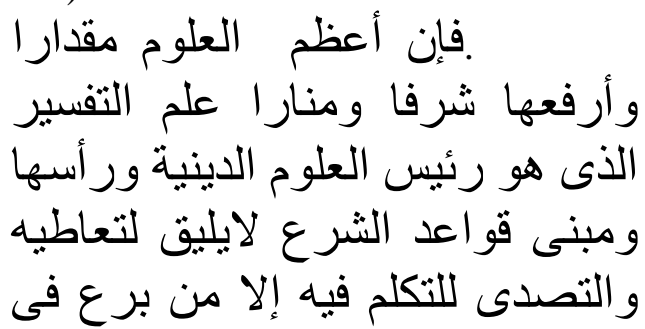


العلوم الدينية كلها أصولها وفرو عها وفاق فى الصناعات العربية و الفنون<smiles>[AlH2][AlH2]</smiles>

Kedua, Imam al-Baidhawi mengatakan bahwa ia telah lama berkeinginan untuk menulis disiplin tafsir dalam bentuk tulisan yang mencakup pikiran-pikiran terbaik yang diperoleh dari para pendahulunya dan ulama yang telah beliau pelajari dari para sahabat, tabi'in dan kaum salaf; buku yang mencakup pula bacaan (qiraat) dari delapan imam dan berbagai model bacaan lain dari qari yang diakui. Tetapi karena beliau menyadari keterbatasan kemampuannya maka beliau menangguhkan usaha penulisan kitab tafsirnya. Jelas disini, bahwa Imam al-Baidhawi telah mencoba untuk menulis tafsir ini namun karena ketidakmampuan untuk melakukan itu, kemudian Beliau menundanya sampai menjelang akhir hayatnya. Beliau menulis sebagai berikuit: (Umar bin Muhammad al-Syiraji al-Baidhawi, : 5-6)

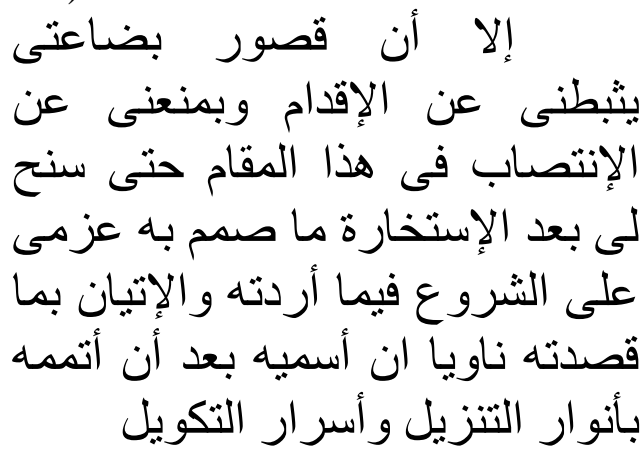

Sementara itu, menurut Muhammad al-Fadhil ibn 'Ashur, tafsir al-Baidhawi ditulis pada akhir hidupnya yakni paruh kedua abad ketujuh di Tibriz. (Ibn 'Ashur, AlTafsir wa Rijaluhu, 1966): 97)

Melalui pernyataan Imam alBaidhawi dalam pengantarnya serta penelusuran terhadap kitab Tafsîr Anwâr al-Tanzîl wa Asrâr al-Takwîl penulis menemukan beberapa metode hermeneutika Al-Baidhawi, diantaranya adalah :

\section{Memberikan perhatian mendalam terhadap tata bahasa Arab.}

Dalam persoalan ini, AlBaidhawi menjelaskan kata-kata dan istilah-istilah yang kurang jelas. Beliau juga menjelaskan hubungan yang erat antara satu kata dengan kata yang lain. Tampak sekali penguasaan Beliau terhadap beberapa karya ahli tata bahasa Arab seperti halnya Sibawaih, al-Khalil, al-Mubarrad, Tsalab dan lainnya yang sering disebut-sebut dalam tafsirnya. Tidak jarang Beliau juga mengutip petikan sya'ir para pujangga Arab.

Sebagai misal ketika menafsirkan Alhamdulillah, Imam Baidhawi menulis

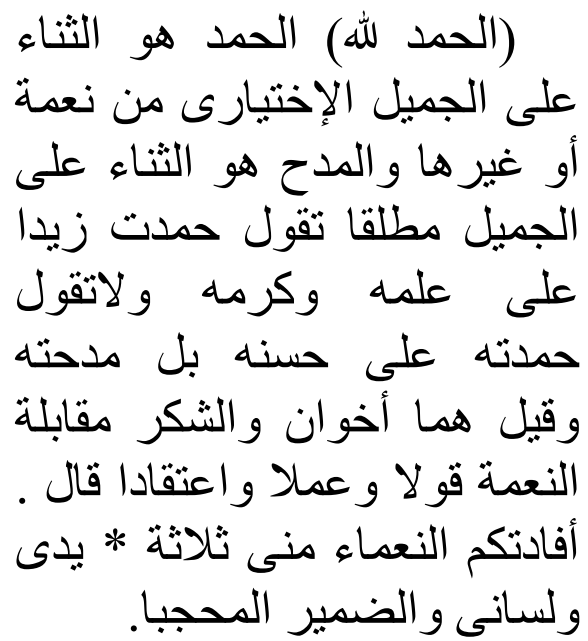

Atau ketika menjelaskan Alif Lam Mim pada permulaan surah alBaqarah Beliau menulis;

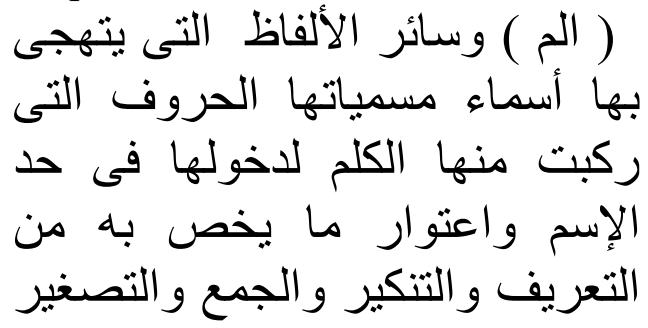




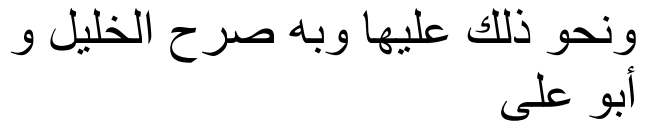

Dalam uraian yang berkaitan dengan tata bahasa tersebut seringkali Imam al-Baidhawi merujuk kepada tafsir al-Kasysyaf karya Zamakhsyari. Hal tersebut dapat diketahui dari penjelasan komentator (penulis hasyiyah) tafsir Al-Baidhawi sendiri. Misalnya AlKazaruni mengomentari penjelasan kebahasaan Imam Baidhawi dalam tafsirnya dengan perkataan فصرح أى صناحب الكثاف, كذا فى الكثاف atau هذا القاءل صاحب الكثافى dan pernyataan lainnya. Namun ada kalanya uraian Imam Baidhawi justru menolak pendapat Zamakhsyari yang disajikan dalam al-Kasysyaf. Al-Kazaruni mengomentari sikap oposan Imam Baidhawi terhadap penjelasan فيه رد على الكثاف.

\section{Mengangkat munasabah ayat (internal relationship)}

Metode hermeneutika AlBaidhawi yang lain adalah apa yang disebut oleh para pemerhati tafsir dengan munasabah ayat (internal relationship), yaitu hubungan internal dalam al-Quran yang sering القران يفر diistilahkan dengan

\section{(ayat-ayat al-Quran} saling menafsirkan satu sama lain). Praktek ini misalnya dapat dilihat ketika Imam Baidhawi menafsirkan ayat ke 56 dari surah al-Rum yang berbunyi لقد لبثتم فى كتاب الهـ Sesungguhnya kamu telah berdiam [dalam kubur] menurut ketetapan Allah).

Cara penafsiran Imam Baidhawi terhadap ayat diatas adalah dengan menghubungkannya dengan ayat ke 100 dari surah alومن Mukminun yang berbunyi ورائهم برزخ ( Dan di hadapan mereka ada dinding ) untuk menjelaskan bahwa ayat yang terakhir disebut mempunyai arti yang sama dengan dengan ayat yang sedang ia tafsirkan.

3. Merekam riwayat pendukung (asbab al-nuzul) serta

komentar shahabat, tabi'in

dan ulama salaf atau mufassir-mufasir sebelumnya.

Peran hadits dalam tafsir Imam Baidhawi lebih nyata dibanding dengan peran al-Quran. Sebagai misal, ketika menafsirkan surah al-Rum, Imam al-Baidhawi mengutip sekitar tiga fungsi hadits. Pertama, Beliau memulai penafsiran dengan hadits yang merekam latar belakang historis turunnya ayat (asbab al-nuzul). Kedua, Beliau mengutip hadits yang menerangkan arti suatu ayat. Seperti dalam menafsirkan ayat ke 47 surah al-Rum yang berbunyi ;

$$
\text { وكان حقا علينا نصر المؤمنين }
$$

berkewajiban menolong orang-orang yang beriman"Imam al-Baidhawi mengutip sabda Rasulullah SAW yang berbunyi;

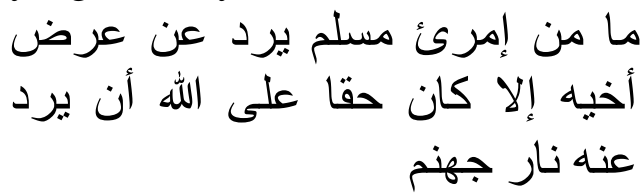

"Setiap muslim yang menjaga kehormatan saudaranya maka Allah akan menjaganya dari api neraka".

Ketiga, Beliau mengutip hadits-hadits fadhail al-suwar pada penghujung setiap surah yang ditafsirkan. Namun sayangnya, ketika mengutip hadits tersebut, 
Imam al-Baidhawi tidak menyebutkan sandaran periwayatan yang mempengaruhi otentisitas dan validitas hadits tersebut. Kategori haditst-hadits tersebut sering dikategorikan dengan hadits dlaif bahkan hadits maudhu oleh sementara pemerhati validitas hadits. Kajian tentang hadits-hadits yang berkaitan dengan keutamaan surah dalam al-Quran telah dibahas penulis dengan cukup gamblang dalam sebuah tulisan yang berjudul Fadhail al-Suwar, Studi teks hadits tentang keutamaan surah-surah dalam Al-Quran. Seperti ketika menyebutkan keistimewaan surah alRum tersebut, Imam al- Baidhawi mengutip hadits Nabi SAW yang berbunyi;

من قرء سورة الروم كان لله من الأجر عشر حسنات بعدد كل ملاء سبح الله بين السماء و الأرض وض وأدرك ما ضيع فى يو مه وليلته

"Barangsiapa membaca surah alRum maka ia akan memperoleh sepuluh kebaikan sejumlah keseluruhan malaikat yang membaca tasbih diantara langit dan bumi serta akan meraih sesuatu yang tersia-sia pada saat siang dan malam. (alBaidhawi:142-150)

Kemudian

ketika menafsirkan ayat-ayat yang berkaitan dengan kisah umat-umat yang terdahulu, Imam Baidhawi terkadang mengutip riwayat Israiliyyat namun tidak banyak. Misalnya ketika menafsirkan surah al-Naml ayat 22, yang berbunyi ;

$$
\begin{aligned}
& \text { فمكث: غير بعيد فقال أحطت بما لـ } \\
& \text { تحط به وجئنك من سبإ بنبا يقين } \\
& \text { "Maka tidak lama kemudian } \\
& \text { (datanglah hud-hud), lalu ia } \\
& \text { berkata:"Aku telah mengetahui } \\
& \text { sesuatu yang belum kamu ketahui ; }
\end{aligned}
$$

dan kubawa kepadamu dari negeri Saba suatu berita penting yang diyakini".

Imam al- Baidhawi mengutip riwayat yang berbunyi; (AlBaidhawi: 142-150)

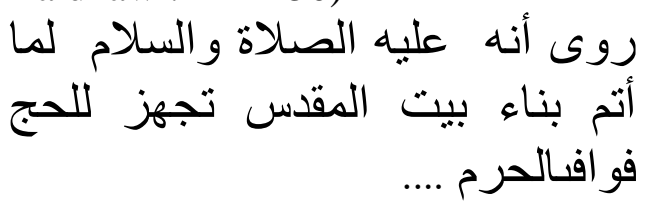

Dalam tafsir al-Baidhawi ini ada kesan kuat bahwa Imam alBaidhawi sangat bergantung kepada para mufssir pendahulunya. Beliau seringkali menyebut nama Ibnu Abbas. Kemudian ada juga nama sahabat seperti Ibnu Mas'ud, Ubay bin Ka'ab, Abdullah bin Zubair, Abu Mus al-Asy'ari dan Zaid bin Tsabit. Juga ada nama-nama tabi'in seperti Mujahid, Al-Dhahhak, Qatadah, Ikrima dan Abu al-'Ali. Sebagian ahli menamakan kelompok sahabat dan tabi'in sebagai mufassir periode formatif, yakni tafsir-tafsir al-Quran yang berlangsung dari masa Nabi Muhammad SAW sampai masa alThabari.

Adapun berkaitan dengan para penulis kitab tafsir sebelumnya, memang unik, ketika Imam Baidhawi tidak pernah menyebut nama-nama seperti al-Thabari, Zamakhsyary, al-Razi ataupun alRagib al-Isfahani walaupun para penulis hasyiyah dapat menemukan bahwa apa yang Beliau tulis seringkali merujuk kepada namanama mufassir tersebut.

\section{Memperhatikan teknik pembacaan al-Quran (qiraat)}

Selain mengutip pendapat shahabat, tabi'in serta para ulama sebelumnya, Imam Baidhawi sangat memperhatikan teknik pembacaan alQuran. Kita maklumi bersama bahwa cara membaca ayat al-Quran dapat 
mengakibatkan perbedaaan arti. Berkaitan dengan teknik qiraat ini, Imam Baidhawi tidak hanya menyajikan tujuh teknik pembacaan yang dikenal dengan qiraah alsab'ah, melainkan juga menambah satu qari lagi sehingga jumlahnya menjadi delapan, yakni qari Ya'qub al-Hadhrami. Ia bernama lengkap Abu Muhammad Ya'qub bin Ishak al-Hadhrami. Periwayat dari qiraat Ya'qub yang terkenal diantaranya adalah Rauh bin 'Abd al-Mukmin dan Muhammad bin Mutawakkil alLu'lui yang dijuluki Ruwais.Ya'qub merupakan salah seorang dari sepuluh imam yang menjadi rujukan teknik pembacaaan ayat-ayat alQuran setelah Ibnu Amir, Ibnu Katsir, 'Ashim, Abu 'Amr, Hamzah, Al-Kisai dan Abu Ja'far.Tiga dari sepuluh qiraat yang diperhitungkan oleh para ahli selain yang terkenal dengan qira'at al-sab'ah diperselisihkan para ulama otentisitasnya. Menurut Ibnu Subki mutawatir, menurut Jalaluddin alMahalli sah-sah saja, sedangkan menurut Fuqaha yang memandang hanya qira'at sab'ah yang mutawatir, tiga qiraat tersebut seluruhnya syadz. Uniknya, Imam alBaidhawi yang dikenal sebagai seorang faqih itu menggunakan Ya'qub sebagai salah seorang imam yang dijadikan sandaran rujukan qiraat dalam kitab tafsirnya ( Muhammad Abdul 'Azhim alZarqani, 1988: 440-463).

.Ketika menafsirkan ayat ke 30 dari surah al-Rum, nama Ya'qub dikutip tiga kali oleh Imam Baidhawi

Contoh penafsiran dengan pendekatan qiraat dapat dilihat ketika Imam Baidhawi menafsirkan ayat keempat dari al-Quran surah alملك يوم Fatihah yang berbunyi Imam Baidhawi mengatakan bahwa lafadz yang dibaca dengan dipanjangkan mim-nya adalah qiraat 'Ashim, al-Kisai dan Ya'qub. Bacaan tersebut diperkuat dengan ayat ke 19 dari surah al-Infithar yang berbunyi ;

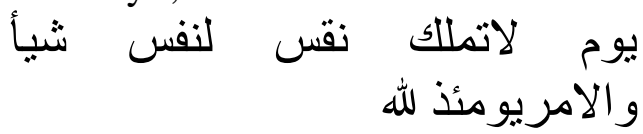

"(Yaitu) hari (ketika) seseorang tidak berdaya sedikitpun untuk menolong orang lain. Dan segala urusan pada hari itu dalam kekuasaan Allah".

Sehingga ayat diatas dimaknai dengan "Yang Menguasai hari pembalasan" (pen.). Adapun ulama yang lain membaca dengan dipendekkan mim-nya. Imam alBaidhawi memilih qiraat ini dengan argumen bahwa pembacaaan mim yang pendek merupakan qiraat pilihan yang dipraktekkan oleh penduduk Mekah dan Madinah (Ahlu Haramain). Pemahaman ayat tersebut diperkuat dengan firman Allah SWT dalam surah al-Mukmin لمن الملك اليوم ayat 16 yang berbunyi "Kepunyaan siapakah kerajaan pada hari ini ?". Sehingga ayat tersebut ditafsirkan dengan "Yang Merajai hari pembalasan".

\section{Ekspose paham kalam dan fikih.}

Dalam kajian hermeneutika, latar belakang akademis mufassir akan mempengaruhi cara pembacaan dan penafsirannya terhadap teks. Oleh karenanya sangat wajar sekali seandainya Imam Baidhawi menghiasi tafsirnya dengan pahampaham yang dianutnya. Sebagai seorang pengikut Asy'ari dalam madzhab kalam, Imam Baidhawi melakukan kontra interpretatif terhadap paham-paham Muktazilah yang dilansir Zamakhsyari dalam kitab tafsir al-Kasysyaf. Sedangkan 
sebagai pengikut Imam Syafi'i, beliau gigih mengaplikasikan paham Syafi 'iyyah dalam ayat-ayat hukum.

Sebagai misal, Imam alBaidhawi memulai tulisan dalam الحمد الله نزل الفرقان على عبده ليكون Pernyataan ini merupakan bentuk penolakan terhadap doktrin bahwa al-Quran diciptakan (makhluq) sebagaimana dikemukakan Zamakhsyari pada permulaan kitab al-Kasysyaf. (AlZamakhsyari,:1)

Dalam persoalan fiqih, Imam al-Baidhawi kentara sekali dukungannya terhadap Imam Syafi'i. Misalnya ketika Imam al-Baidhawi menafsirkan ayat

Bismillahirrahmanirrahim. Pertama kali Imam al-Baidhawi menegaskan bahwa Bismillahirrahmanirrahim adalah bagian dari surah al-Fatihah dan seluruh surah dalam al-Quran sebagaimana dianut para ahli qiraat serta fuqaha Mekah dan Kufah, juga Ibnu Mubarak dan Imam Syafi'i. Berbeda halnya dengan para ahli qiraat dan fuqaha Madinah, Bashrah dan Syam, juga Imam Malik serta Imam Auza'i. Kemudian Imam alBaidhawi mengutip dialog Muhammad bin Hasan yang mempertegas kedudukan Bismillahirrahmanirrahim sebagai bagian dari surah al-Fatihah dengan mengutip hadits Rasulullah sebagai pendukungnya.

\section{Interpretasi ilmiah terhadap ayat-ayat yang terkait ilmu pengetahuan}

Dalam menafsirkan ayat-ayat yang berhubungan dengan alam semesta dan ilmu-ilmu kealaman, Imam al-Baidhawi sangat terpengaruh oleh metode penafsiran
Imam al-Razi dalam tafsir Mafatih al-Ghaib. Sebagaimana Imam alRazi yang ahli dalam bidang ilmu alam menafsirkan dengan panjang lebar ayat-ayat yang berkaitan dengan ilmu tersebut, maka Imam alBaidhawipun banyak sekali berbicara mengenai persoalan astronomi, langit, bumi, hujan, awan, hewan, tumbuhan dan manusia serta yang lainnya.

Karena pembahasan yang begitu luas terhadap ayat-ayat alam, tak kurang ulama seperti Dr. Abdul Majid Abdul Salam al-Muhtasib memasukkan tafsir Imam alBaidhawi ini ke dalam Tafsir 'Ilmi Tafsir 'ilmi yang merupakan ijtihad atau usaha keras mufassir untuk mengungkap hubungan ayat-ayat kauniyah dalam al-Quran dengan penemuan-penemuan ilmiah yang bertujuan untuk memperlihatkan kemukjizatan al-Quran. (Abdul Majid Abdul salam al-Muhtasib :252-253). Dan karena itu pula diantaranya -menurut hemat penulis- tafsir al-Baidhawi dikategorikan oleh sementara ulama sebagai tafsir bi al-ra'yi.

\section{KESIMPULAN}

Sebagai penutup dari makalah sederhana ini, ada beberapa catatan akhir yang hendak penulis sampaikan, diantaranya adalah:

1. Dalam kitab tafsir Anwar alTanzil wa Asrar al-Takwil, Imam al-Baidhawi tidak hanya melakukan penafsiran, tetapi juga pentakwilan terhadap ayatayat al-Quran dengan pendekatan kaidah bahasa Arab.

2. Imam al-Baidhawi menyajikan ayat-ayat hukum yang berkenaan dengan masalah fikih secara ringkas dengan menunjukkan 
kecenderungannya terhadap Mazhab Syafi'i yang dianutnya.

3. Ada dua kitab tafsir penting yang dirujuk Imam al-Baidhawi dalam menyusun kitab tafsir ini. Pertama, kitab Tafsir alKasysyaf karya al-Zamakhsyari, namun beliau meninggalkan pendapat al-Zamakhsyari yang berhubungan dengan paham Muktazilah. Kedua, kitab AlTafsir al-Kabir karya Fakhruddin al-Razi yang menyebabkan Imam Baidhawi tenggelam dalam pembahasan tentang ayat-ayat yang berhubungan dengan fenomena alam sehingga mengantarkan karya tafsirnya kedalam corak tafsir ilmi.

\section{DAFTAR PUTAKA}

Al-Asnawi, Jamaluddin Abdulrahim, Thabaqat al-Syafi'iyyah, Dar al-kitab al-Ilmiah, Beirut, tt.

Al-Baidhawi, Umar bin Muhammad al-Syiraji, Anwar al-Tanzil wa Asrar al-Takwil, Al-Haramain, Singapura, tt.

Al-Dawudi, Ahmad, Thabaqat alMufassirin, Dar al-kutub alIlmiah, Beirut, tt.

Al-Dzahabi, Muhammad Husein, alTafsir wa al-Mufassirun, Dar el-Fikr, Beirut, 1976. AlFakhrurazi, Mafatih al-Ghaib, Dar alKutub al-Ilmiah, Beirut, tt.
Al-Maraghi, Mushtafa Ahmad, Tafsir Al-Maraghi, Dar el-Fikr, Mesir, 1974.

Al-Muhtasib, Abdul Mujib Abdul salam, Dr, Ittijahat al-tafsir fi 'Ashr al-Hadits, Dar al-Fikr, Beirut, 1973.

Al-Zamakhsyari, Al-Kasysyaf, Dar al-Fikr, Beirut, tt.

Al-Zarqani, Muhammad Abdul 'Azhim, Manahil al- 'Irfan, Dar al-fikr, Beirut, 1988

Ibn 'Ashur, Al-Tafsir wa Rijaluhu, Dar al-Kutub al-Syarqiyyah, Tunis, 1966.

Jeanrond, Warner G, Theological Hermeneutics : Development and Signfinance, Crossroad, New York, 1991.

Jurnal Ulumul Quran No. 3 /VII/1996.

Ritonga, Rohman, et.al, Ensiklopedia Hukum Islam, P.T. Ichtiar Baru Van Hoeven, Jakarta, 1997.

Shihab, M. Quraish, et.al, Sejarah \& Ulum Al-Quran, Pustaka Firdaus, Jakarta, 2000.

Thiselton, Antony. C., New Horizons in Hermeneutics, Zondervan, Michigan, 1992.

Watt, W. Montgomery, Bell's Introduction to the Qur'an, Terj. Lilian D. Tedjasudhana, Richard Bell : Pengantar Quran, INIS, Jakarta, 1998 